17. Bowman E, Markand O. Psychodynamics and psychiatric diagnoses of pseudoseizure patients. Am J Psychiatry 1996; 153:57-63.

18. Rosenberg HJ, Rosenberg SD, Williamson PD, Wolford GL. A comparative study of trauma and posttraumatic stress disorder in prevalence in epilepsy patients and psychogenic nonepileptic seizure patients. Epilepsia 2000;41:447-452.

19. Hudak A, Trivadi K, Harper C, et al. Evaluation of seizure-like episodes in survivors of moderate to severe traumatic brain injury. J Head Trauma Rehabil 2004;19: $290-295$.

20. Westbrook LE, Devinsky O, Geocadin R. Nonepileptic seizures after head injury. Epilepsia 1998;39:978-982.

21. Barry E, Krunholz A, Bergey GK, Chatha H, Alemayehu S, Grattan G. Nonepileptic posttraumatic seizures. Epilepsia 1998;39:427-431.

22. Kanner A, Parra J, Frey M, Stebbins G, Pierre-Louis S, Iriarte J. Psychiatric and neurologic predictors of psychogenic pseudoseizure outcome. Neurology 1999;53:938.
23. D’Alessio L, Giagante B, Oddo S, et al. Psychiatric disorders in patients with psychogenic nonepileptic seizures, with and without comorbid epilepsy. Seizure 2006;15: 333-339.

24. Goldstein LH, Chalder T, Chigwidere C, et al. Cognitivebehavioral therapy for psychogenic nonepileptic seizures. Neurology 2010;74:1986-1994.

25. LaFrance WC, Alper K, Babcock D, et al. Nonepileptic seizures treatment workshop summary. Epilepsy Behav 2006;8:451-461.

26. Martin R, Gilliam FG, Kilgore M, Faught E, Kuzniecky R. Improved health care resource utilization following videoEEG confirmed diagnosis of nonepileptic seizures. Seizure 1998;7:385-390.

27. Lempert T, Schmidt D. Natural history and outcome of psychogenic seizures: a clinical study in 50 patients. J Neurol 1990;237:35-38.

28. Buchanan N, Snars J. Pseudoseizures: clinical management and outcome in 50 patients. Seizure 1993;2:141-146.

\title{
$\frac{+}{\text { CELEBRATING } 60 \text { YEARS }}$ \begin{tabular}{l} 
CELEBRATING 60 YEARS \\
OF PUBLICATION \\
\hline
\end{tabular} $+++$ \\ Neurology \\ Historical Abstract: August 1, 1993
}

\section{ASSOCIATION OF APOLIPOPROTEIN E ALLELE $\varepsilon 4$ WITH LATE-ONSET FAMILIAL AND SPORADIC ALZHEIMER'S DISEASE}

A.M. Saunders, PhD; W.J. Strittmatter, MD; D. Schmechel, MD; P.H. St. George-Hyslop, MD; M.A. Pericak-Vance, PhD S.H. Joo, BS; B.L. Rosi, BA; J.F. Gusella, PhD; D.R. Crapper-MacLachlan, MD; M.J. Alberts, MD; C. Hulette, MD; B. Crain, MD; D. Goldgaber, PhD; and A.D. Roses, MD

Neurology August 1993;43:1467-1472

Apolipoprotein E, type $\varepsilon 4$ allele (APOE $\varepsilon 4$ ), is associated with late-onset familial Alzheimer's disease (AD). There is high avidity and specific binding of amyloid $\beta$-peptide with the protein ApoE. To test the hypothesis that late-onset familial AD may represent the clustering of sporadic AD in families large enough to be studied, we extended the analyses of APOE alleles to several series of sporadic $\mathrm{AD}$ patients. APOE $\varepsilon 4$ is significantly associated with a series of probable sporadic AD patients $(0.36 \pm 0.042, \mathrm{AD}$, versus $0.16 \pm 0.027$, controls [allele frequency estimate \pm standard error], $p=0.00031$ ). Spouse controls did not differ from CEPH grandparent controls from the Centre d'Etude du Polymorphisme Humain (CEPH) or from literature controls. A large combined series of autopsy-documented sporadic AD patients also demonstrated highly significant association with the APOE $\varepsilon 4$ allele $(0.40 \pm 0.026$, $p \leq 0.00001$ ). These data support the involvement of ApoE $\varepsilon 4$ in the pathogenesis of late-onset familial and sporadic AD. ApoE isoforms may play an important role in the metabolism of $\beta$-peptide, and APOE $\varepsilon 4$ may operate as a susceptibility gene (risk factor) for the clinical expression of $\mathrm{AD}$

Free Access to this article at www.neurology.org/content/43/8/1467

Comment from David S. Knopman, MD, FAAN, Deputy Editor: Although this was not the very first report of APOE'S role in AD, this article has been widely cited. Few realized at the time how much of an impact characterization of APOE would have on AD research. 


\section{Neurology}

\section{Association of apolipoprotein $\mathrm{E}$ allele $\varepsilon 4$ with late-onset familial and sporadic Alzheimer's disease}

A.M. Saunders, W.J. Strittmatter, D. Schmechel, et al. Neurology 2011;77;950

DOI 10.1212/01.wnl.0000405291.74999.10

This information is current as of September 5, 2011

\section{Updated Information \&} Services

Permissions \& Licensing including high resolution figures, can be found at: http://n.neurology.org/content/77/10/950.citation.full

Information about reproducing this article in parts (figures,tables) or in its entirety can be found online at:

http://www.neurology.org/about/about_the_journal\#permissions

Reprints
Information about ordering reprints can be found online: http://n.neurology.org/subscribers/advertise

Neurology ${ }^{\circledR}$ is the official journal of the American Academy of Neurology. Published continuously since 1951, it is now a weekly with 48 issues per year. Copyright Copyright $@ 2011$ by AAN Enterprises, Inc.. All rights reserved. Print ISSN: 0028-3878. Online ISSN: 1526-632X.

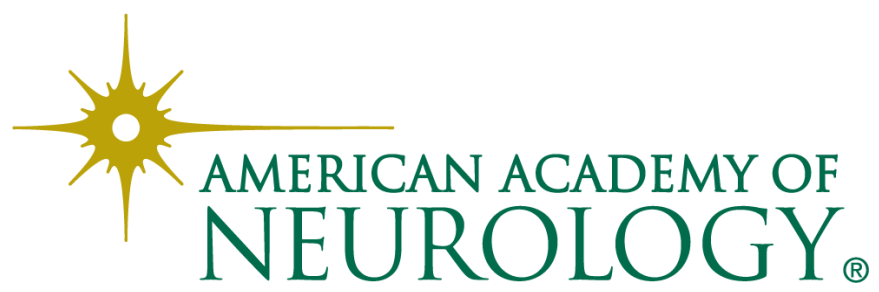

